\title{
A NOVEL 6 DOF THRUST VECTOR CONTROL TEST STAND
}

\author{
Predrag Miloš, Nikola Davidović, Branislav Jojić, Marko Miloš, Ivana Todić
}

Original scientific paper

This study proposes an innovative test stand design to accurately measure rocket motor thrust vector during its operation. Test stand design is clearly presented as well as procedure and mathematical model for its calibration. A method of processing data obtained from the experiments and the results of the jet tab system for thrust vector control are presented in detail. Experiments have shown that the test stand is highly functional and the results obtained have excellent repeatability and matching with the results of the other authors who have used different construction test stands for measurement of the same or a similar mechanism for thrust vector control.

Keywords: jet tab; rocket motor; test stand; thrust vector control

Novi ispitni stol sa šest stupnjeva slobode za ispitivanje upravljanja vektorom potiska

U ovom radu se predlaže inovativnu konstrukciju ispitnog stola za precizno mjerenje vektora potiska raketnog motora tijekom njegovog rada. Jasno je izložena konstrukcija ispitnog stola kao i procedure te matematički model za kalibraciju ispitnog stola. Metoda obrade podataka dobivenih ispitivanjem kao i rezultati ispitivanja "jet tab" sustava za upravljanje vektorom potiska detaljno su prezentirani. Eksperimenti su pokazali da je ispitni stol iznimno funkcionalan, a da dobineni rezultati imaju odličnu ponovljivost i poklapanje s rezultatima autora koji su koristili ispitne stolove drugačije konstrukcije za mjerenje istog ili sličnog mehanizma za upravljanje vektorom potiska.

Ključne riječi: ispitni stol; jet tab; raketni motor; upravljanje vektorom potiska

\section{Introduction}

Most vehicles used for launching spacecraft require some guidance or steering to ensure that the required flight trajectory will be achieved. In addition, steering is needed to compensate for flight disturbances (winds) and for vehicle imperfections (misalignment of thrust and center of gravity). To provide steering solid propellant rocket motors are equipped with a TVC system [6].

TVC systems are classified primarily by nozzle type, either fixed or movable, and secondly by the method of providing actual thrust vector control [1].

Mechanical systems are based on different mechanical obstacles, which are used to modify flow around obstacle and/or in the nozzle and thus pressure distribution. Both aerodynamic and mechanical techniques have been used to redirect the motor thrust and provide steering forces. Aerodynamic techniques have demonstrated very rapid response rates, but also suffer motor thrust losses at large TVC vector angles. The higher losses with the aerodynamic jet tab, jet vanes and bleed control concepts are a result of the physical creation of side force by creating a shock pattern in the exit cone thrust i.e. the higher the TVC angle required, the larger the percentage of thrust involved. Jet tabs or vanes have been used for rapid thrust vector control steering, especially early in flight when missile speeds are too low to achieve effective control with external aerodynamic fins. These systems usually require tungsten or refractory metal components to minimize the erosion from the solid particles in the hot exhaust gas. The jet tab TVC system has low torque, and is simple for missiles with low-areratio nozzles. Its thrust loss is high when tabs are rotated at full angle into the jet, but is zero when the tabs are in their neutral position outside of the jet. On most flights the time-averaged position of the tab is a very small angle and the average thrust loss is small. Jet tabs can form a very compact mechanism and have been used successfully on tactical missiles. Four tabs, independently actuated, rotated in and out of the motor's exhaust jet during rocket motor operation provide control of a vehicle's pitch, yaw and roll motions [2, 8, 9]. Side forces and roll torques are usually relatively small compared to the main thrust and the pitch or yaw torques. Their accurate static test measurement can be difficult, particularly at low vector angles. Multi-component test stands employing multiple load cells and isolation flexures are needed to assure valid measurements.

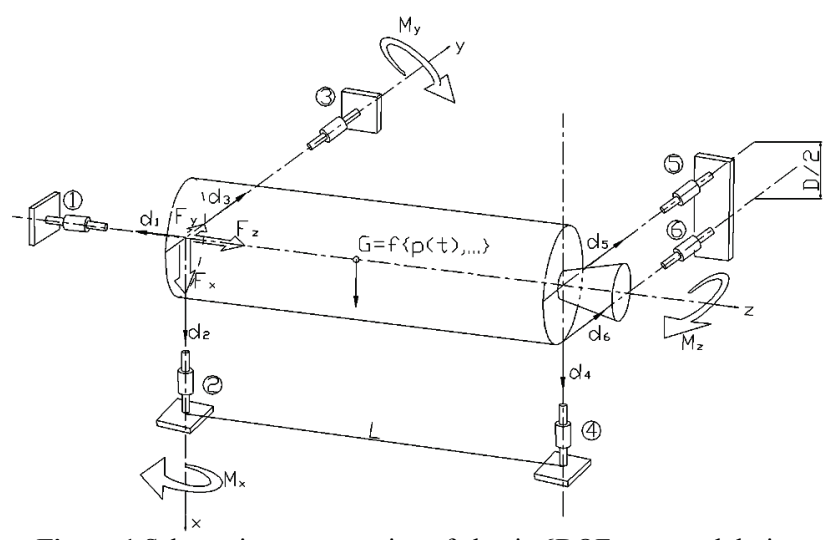

Figure 1 Schematic representation of classic 6DOF test stand design

Solid rocket motor is defined in mechanical terms as a rigid body with six degrees of freedom and the forces and moments produced by them are external forces. Rocket motor is tested on the test stand, which is a standalone assembly or part of a more complex experiment installation. By attaching a rocket motor to the test stand the experimental measurement of forces and moments is realized by movement simulation of one or more degrees of freedom. In doing so by design it is achieved that all elements and generated links meet the requirements of a virtual movement under the action of external (generalized) forces. Thereby test stand meets the 
requirements of linear operator in the unitary space and allows the forces and moments of rocket motor to be defined by the measured reactions.

Test stands are of different designs, but the most common is the one in which the rocket motor is connected to the basement by the rods (Fig. 1) [5].

In the rods, which are called arms, are placed the force sensors. Arranged arms follow layout of the Descartes coordinate system. Connections arm-motor and arm-stand are spherical in a static sense; design solutions of joint are bearings and flexures. The coordinate system is set so that one axis coincides with the axis of the rocket motor.

In this paper is presented a novel design of 6 degree of freedom thrust vector control test stand. Its verification is performed on measuring thrust vector angle deflection and thrust losses of jet tab TVC configuration in static conditions and results as a function of nozzle exit area blockage percentage are presented.

\section{Test stand design}

As can be seen in Fig. 2 lower plate of test stand is connected to the basement by the rigid connections-bolts. The upper plate is connected to the lower plate by six rods attached to both plates by the spherical plain bearings. In that way they can only transfer loads along their axis. In this case external loads will be thrust components of rocket motor which is fastened to the upper plate. The system for motor connection with the upper plate also ensures positioning of jet tab always in the same position, perpendicular to the $Y$ axis.

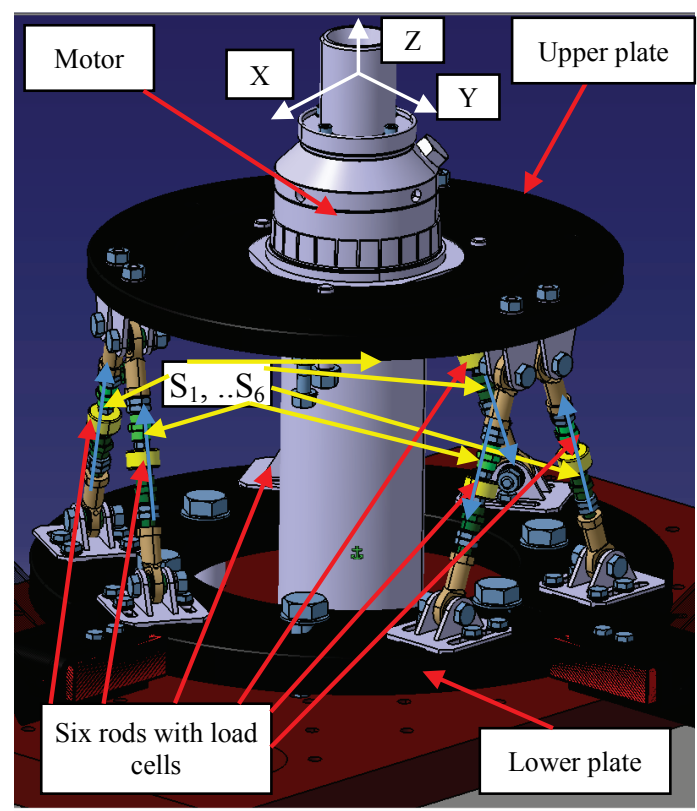

Figure 2 Test stand design

Rods used for upper to lower plate connection have on the ends plain spherical bearing, for connection to the plates, and load cell in the middle capable to measure loads in both directions (compression and tension) which enable the measure test stand response on external loads. Adjustable nuts are used for rod length setting and position locking (Fig. 3).

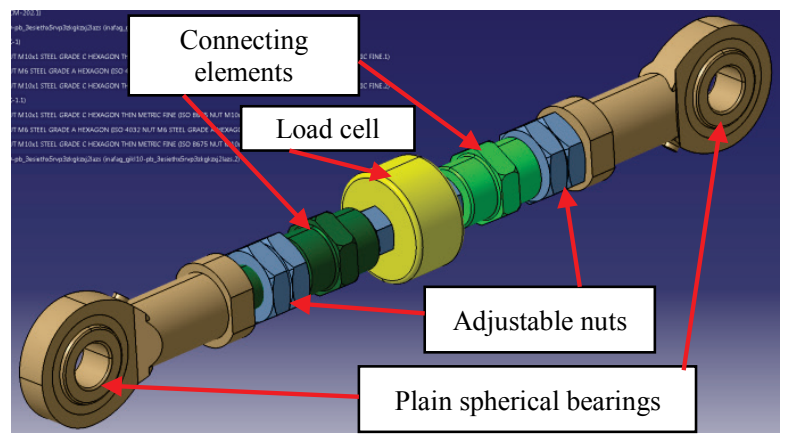

Figure 3 Rod design

In order to calculate applied forces and position of act onto test stand, the system must be fully calibrated which means calibration upon forces along $X, Y$ and $Z$ axes as well as upon the moment around those axes $M_{x}, M_{y}$ and $M_{z}$. In that way is obtained $6 \times 6$ calibration matrix ( $\boldsymbol{A}), \boldsymbol{A}=\left[\begin{array}{ccc}a_{11} & \cdots & a_{16} \\ \vdots & \ddots & \vdots \\ a_{61} & \cdots & a_{66}\end{array}\right]$. Our task now is to solve system of 6 simultaneous linear equations using matrices.

$\boldsymbol{A} \cdot \boldsymbol{F}=\boldsymbol{S}$

where $\boldsymbol{F}$ is load matrix. $\boldsymbol{F}=\left[\begin{array}{c}F_{x} \\ F_{y} \\ F_{z} \\ M_{x} \\ M_{y} \\ M_{z}\end{array}\right]$, and $\boldsymbol{S}$ is matrix of test stand response (values from load cells) $\boldsymbol{S}=\left[\begin{array}{l}S_{1} \\ S_{2} \\ S_{3} \\ S_{4} \\ S_{5} \\ S_{6}\end{array}\right]$. The solution to the system of equations is given by:

$F=A^{-1} \cdot S$,

where $A^{-1}$ is inverse matrix of matrix $\boldsymbol{A}$,

$\boldsymbol{A}^{-1}=\left[\begin{array}{ccc}b_{11} & \cdots & b_{16} \\ \vdots & \ddots & \vdots \\ b_{61} & \cdots & b_{66}\end{array}\right]$

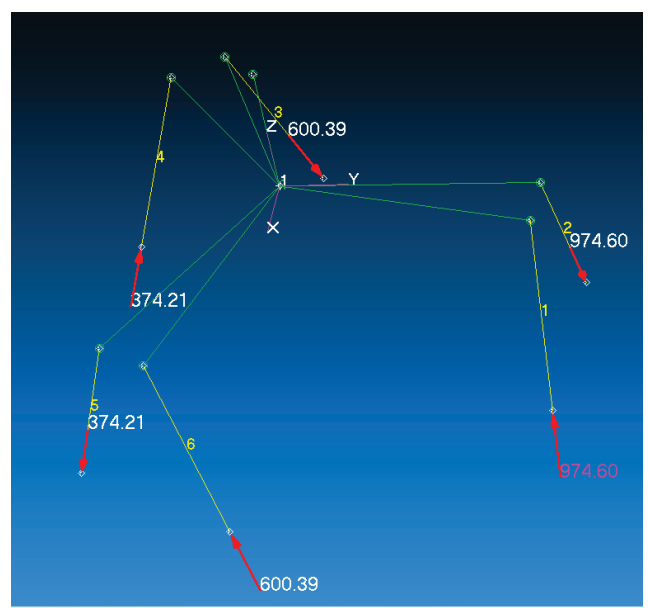

Figure 4 Reactions in rods upon applied load 
A preliminary analysis of the system was performed by usage of software package NASTRAN.

By applying different loads we can obtain reactions on those loads and thus build our calibration matrix $\boldsymbol{A}$ (Fig. 4). As mentioned earlier for measuring jet tab TVC system we will use 4 load cells. This analysis will help to make a choice of the best possible location for load cells. Obviously, three load cells have to be placed symmetrically around the $Z$ axis (rods 1,3 and 5 ; or 2,4 and 6). Here, the first combination will be used, so the last fourth load cell could be placed in positions 2,4 and 6 . In order to determine which position is the best, first calibration matrices have to be calculated for all three cases, after which their condition numbers will be calculated. Condition number of some matrix $\boldsymbol{A}$ is the product of two matrix norms.

$\operatorname{cond}(\boldsymbol{A})=\operatorname{norm}(\boldsymbol{A}) \cdot \operatorname{norm}\left(\boldsymbol{A}^{-1}\right)$

Condition number measures the sensitivity of a linear system solution to errors in input vector. A problem with a low condition number is said to be well-conditioned, while a problem with a high condition number is said to be ill-conditioned. This number clarifies how accurate is expected the vector $\mathrm{x}$ to be, when solving a system of linear equations $A x=b$. So, in solving the equation $A x=b$, the relative error in the solution, divided by the relative error in the right-hand-side vector is given by the condition number of $A$. The following rule of thumb is a useful way to express the above estimate. It states that if $m=\log _{10}(\operatorname{cond}(A))$ then $m$ is the number of digits accuracy lost in solving the system of equations $A x=b$. There is typically additional error due to the many calculations needed in solving the equations. The estimate for additional losses is given by $\log _{10}(n)$ if the matrix $\boldsymbol{A}$ is $n \times n$.

Table 1 Calibration matrix $A_{\mathrm{p} 2}$ with load cell placed on position 2

\begin{tabular}{|c|c|c|c|c|}
\cline { 2 - 5 } & $\begin{array}{c}\text { Load cell } \\
\text { position 1 }\end{array}$ & $\begin{array}{c}\text { Load cell } \\
\text { position 3 }\end{array}$ & $\begin{array}{c}\text { Load cell } \\
\text { position 5 }\end{array}$ & $\begin{array}{c}\text { Load cell } \\
\text { position 2 }\end{array}$ \\
\hline$-M_{x}$ & $-0,20075016$ & 0,1003751 & 0,1003752 & $-0,2007502$ \\
\hline$M_{v}$ & $-1,8 \mathrm{E}-06$ & 0,1738562 & $-0,1738526$ & $2 \mathrm{E}-06$ \\
\hline$F_{z}$ & 0,177363362 & 0,1773634 & 0,17736336 & 0,177363362 \\
\hline$F_{y}$ & 0,07016276 & $-0,879110$ & 0,8089484 & 0,0701628 \\
\hline
\end{tabular}

With condition number: $\operatorname{cond}\left(\boldsymbol{A}_{\mathrm{p} 2}\right)=6,14 \times 10^{5}$

Table 2 Calibration matrix $\boldsymbol{A}_{\mathrm{p} 4}$ with load cell placed on position 4

\begin{tabular}{|c|c|c|c|c|}
\cline { 2 - 5 } \multicolumn{1}{c|}{} & $\begin{array}{c}\text { Load cell } \\
\text { position 1 }\end{array}$ & $\begin{array}{c}\text { Load cell } \\
\text { position 3 }\end{array}$ & $\begin{array}{c}\text { Load cell } \\
\text { position 5 }\end{array}$ & $\begin{array}{c}\text { Load cell } \\
\text { position 4 }\end{array}$ \\
\hline$-M_{x}$ & $-0,20075016$ & 0,1003751 & 0,1003752 & 0,1003752 \\
\hline$M_{y}$ & $-1,8 \mathrm{E}-06$ & 0,1738562 & $-0,1738526$ & 0,1738526 \\
\hline$F_{z}$ & 0,177363362 & 0,1773634 & 0,17736336 & 0,177363362 \\
\hline$F_{y}$ & 0,07016276 & $-0,8791101$ & 0,8089484 & 0,8089484 \\
\hline
\end{tabular}

With condition number: $\operatorname{cond}\left(\boldsymbol{A}_{\mathrm{p} 4}\right)=16,471$

Table 3 Calibration matrix $A_{\mathrm{p} 4}$ with load cell placed on position 6

\begin{tabular}{|c|c|c|c|c|}
\cline { 2 - 5 } \multicolumn{1}{c|}{} & $\begin{array}{c}\text { Load cell } \\
\text { position 1 }\end{array}$ & $\begin{array}{c}\text { Load cell } \\
\text { position 3 }\end{array}$ & $\begin{array}{c}\text { Load cell } \\
\text { position 5 }\end{array}$ & $\begin{array}{c}\text { Load cell } \\
\text { position 6 }\end{array}$ \\
\hline$-M_{x}$ & $-0,20075016$ & 0,1003751 & 0,1003752 & 0,100375 \\
\hline$M_{y}$ & $-1,8 \mathrm{E}-06$ & 0,1738562 & $-0,1738526$ & $-0,173856$ \\
\hline$F_{z}$ & 0,177363362 & 0,1773634 & 0,17736336 & 0,177363362 \\
\hline$F_{y}$ & 0,07016276 & $-0,8791101$ & 0,8089484 & $-0,87911$ \\
\hline
\end{tabular}

$$
\text { With condition number: } \operatorname{cond}\left(\boldsymbol{A}_{\mathrm{p} 6}\right)=16,92
$$

From above results it is obvious that placement of loads cell on position 2 will lead to inaccurate calculation and placement of load cell on positions 4 or 6 will lead to results of the same accuracy.

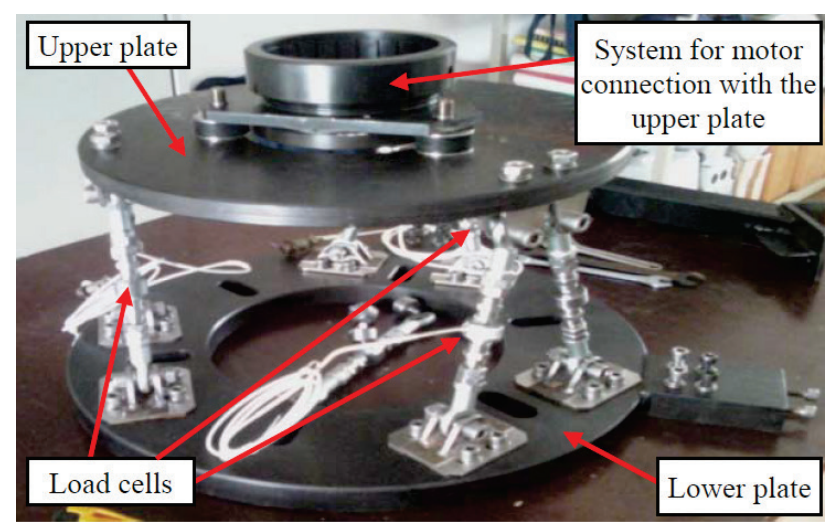

Figure 5 Test stand assembled in laboratory

\section{Test stand calibration}

In order to accurately calculate forces and moments it is necessary to perform precise calibration of the test stand. Because of that special attention was paid to the introduction of the dead-weight loads on the test stand. Load in $\mathrm{Z}$ direction was applied on the test stand over real nozzle mounted on the test stand in the same way as it was during firing test (Fig. 6a). Loads in $X$ (Fig. 6b) and $Y$ (Fig. 6c) direction were applied on the test stand over special pulleys system on two different elevation, along $Z$ axis.

In measuring jet tab TVC system 4 load cells were used and for that reason calibration was performed for two forces $F_{z}$ and $F_{y}$, and two moments $M_{x}$ and $M_{y}$. To accomplish that task it is necessary to perform total of five calibrations, one for $F_{z}$ and two for each moment (calibration of $F_{y}$ is already in $M_{x}$ ) on different elevations from the nozzle (first calibration on the nozzle exit level and second calibration is elevated by approximately 105 $\mathrm{mm}$ ). Miniature, stainless steel universal load cells, with capability to measure in both tension/compression directions, were built in test stand rods. Maximum capacity is $5000 \mathrm{~N}$ and accuracy is $0,25 \%$ FSO linearity, hysteresis, repeatability combined. In the following figures some examples are shown of test stand calibration (positive sign is for compression).

After all five calibrations we are able to form calibration matrix of our test stand using reciprocal values of slopes. This matrix represents reaction in rods (load cells) for applied unity forces (here positive sign is for tension according to the adopted coordinate system, see Fig. 2).

Now it is possible to create matrix $\boldsymbol{A}$ for calculation of applied forces. 

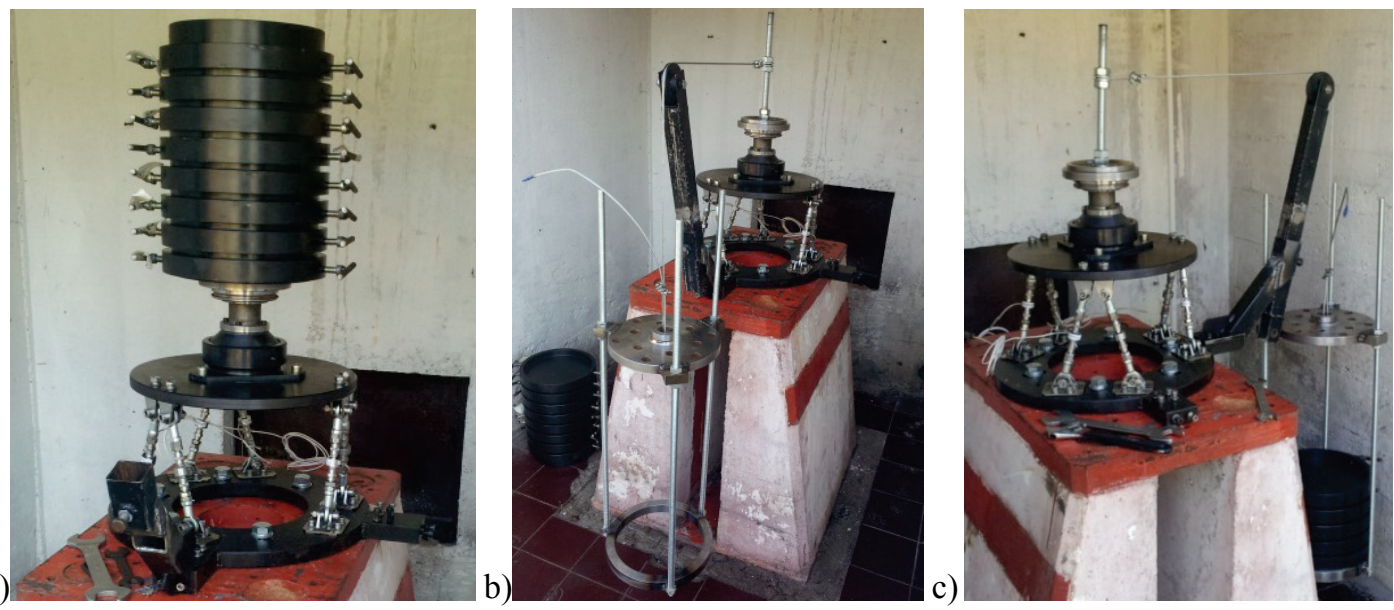

Figure 6 Test stand calibration $Z, X$ and $Y$ axis

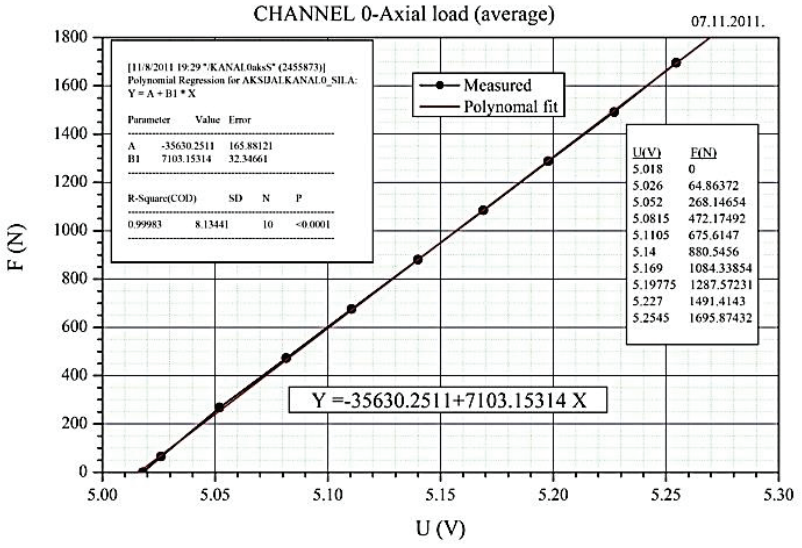

Figure 7 Load cell calibration upon $F_{z}$

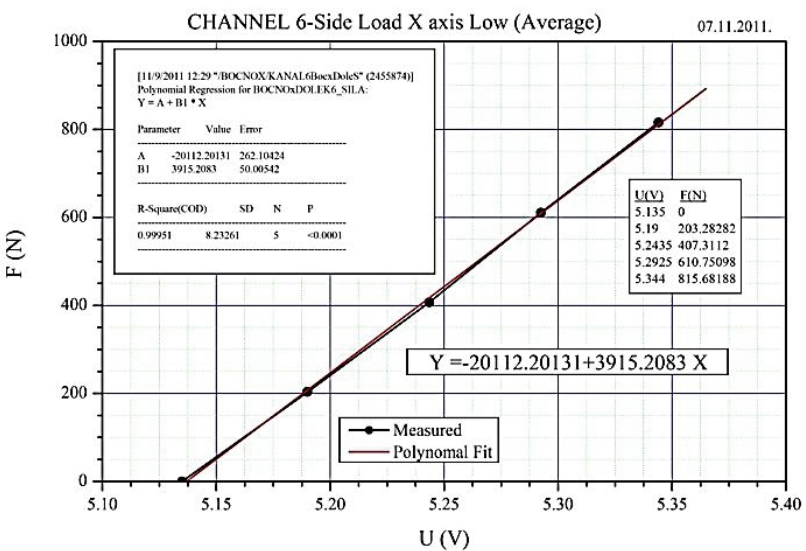

Figure 8 Load cell calibration upon $F_{x}$

Table 4 Calibration matrix

\begin{tabular}{|c|c|c|c|c|c|}
\cline { 2 - 6 } \multicolumn{1}{c|}{} & $\mathrm{F}_{\mathrm{z}}$ & $F_{x}(z=0)$ & $F_{x}(\mathrm{z}=104,8)$ & $F_{y}(z=0)$ & $F_{y}(z=105,5)$ \\
\hline Ch0 & $-0,0001408$ & 0,00105516 & 0,00095490 & 0,00034607 & 0,00050807 \\
\hline Ch1 & $-0,0002015$ & $-0,0008904$ & $-0,0010482$ & 0,00071471 & 0,00060015 \\
\hline Ch2 & $-0,0001400$ & $-0,0001796$ & $-0,0000526$ & $-0,0010525$ & $-0,0011315$ \\
\hline Ch6 & $-0,0000977$ & 0,00025541 & 0,00013558 & $-0,0009143$ & $-0,0009512$ \\
\hline
\end{tabular}

Table 5 Calibration matrix for calculation

\begin{tabular}{|c|c|c|c|c|}
\hline & $F_{z}$ & $F_{v}$ & $-M_{x}$ & $M_{v}$ \\
\hline Ch0 & $-0,000140783$ & 0,000346069 & $1,53552 \mathrm{E}-06$ & $-9,56635 \mathrm{E}-07$ \\
\hline Ch1 & $-0,000201452$ & 0,00071471 & $-1,08584 \mathrm{E}-06$ & $-1,50551 \mathrm{E}-06$ \\
\hline Ch2 & $-0,000139995$ & $-0,001052508$ & $-7,48407 \mathrm{E}-07$ & $1,21182 \mathrm{E}-06$ \\
\hline Ch6 & $-9,76717 \mathrm{E}-05$ & $-0,000914266$ & $-3,50298 \mathrm{E}-07$ & $-1,14351 \mathrm{E}-06$ \\
\hline
\end{tabular}

$-M_{x}=\frac{F y(105,5)-F y(0)}{105,5}$
$M_{y}=\frac{F_{\chi(104,8)}-F_{\chi(0)}}{104,8}$

To calculate loads according to the applied forces, an inverse matrix of matrix $\boldsymbol{A}$ i.e. matrix $\boldsymbol{A}^{-1}$ must be found.

Table 6 Inverse matrix of calibration matrix for calculation

\begin{tabular}{|r|c|c|c|c|}
\cline { 2 - 5 } \multicolumn{1}{c|}{} & Channel 0 & Channel 1 & Channel 2 & Channel 6 \\
\hline$F_{z}$ & $-2430,347703$ & $-1747,597754$ & $-2994,24708$ & 1160,905159 \\
\hline$F_{y}$ & 50,25577932 & 364,4213669 & $-121,232781$ & $-650,3075106$ \\
\hline$-M_{x}$ & 437828,7634 & $-277855,4864$ & $-23075,9609$ & $-24915,4628$ \\
\hline$M_{y}$ & 33282,36543 & $-56978,29029$ & 359749,6158 & $-446089,6077$ \\
\hline
\end{tabular}

\section{Rocket motor}

Rocket motor (RM) used for testing, was of a slotted propellant grain configuration. Length of slots was tailored to provide neutral burning (pressure and thrust versus time are almost without changes - neutral). Graphite nozzle throat was used in order to eliminate throat erosion. Exit diameter of nozzle is $47 \mathrm{~mm}$, the expansion ratio is 5 and half divergent angle is 20 degrees. It is possible to attach different obstacles (tabs) to the exit nozzle surface in order to block desired percentage of exit area. Tabs are made from molybdenum to withstand high thermal loads. Propellant used in test is thermo-plastics composite propellant with $1,5 \%$ of aluminum powder. Total pressure in nozzle was also measured during motor burning time.

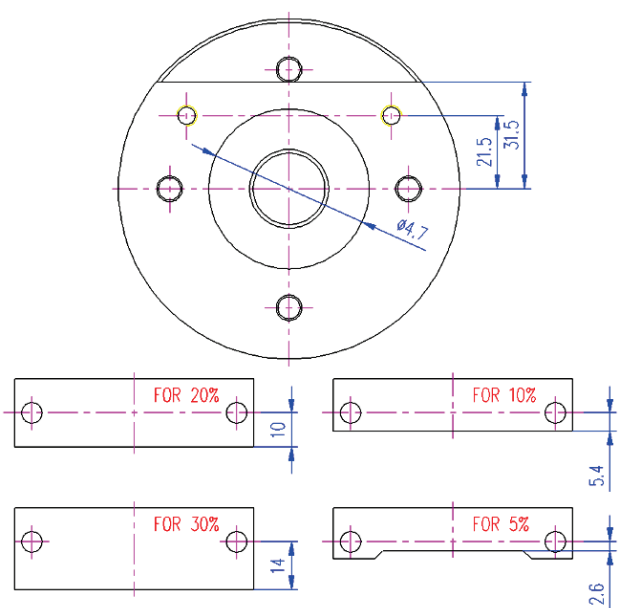

Figure 9 Nozzle exit surface and used tabs geometry 


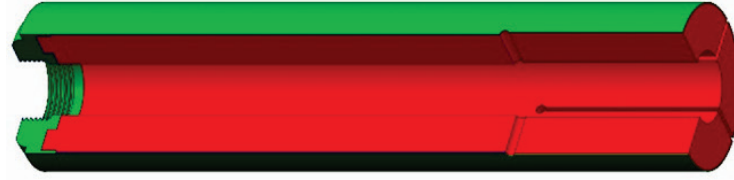

Figure 10 Propellant grain

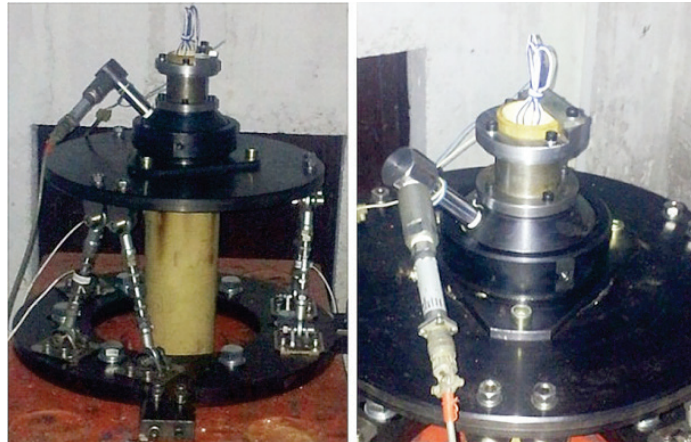

Figure 11 Rocket motor on test stand before firing

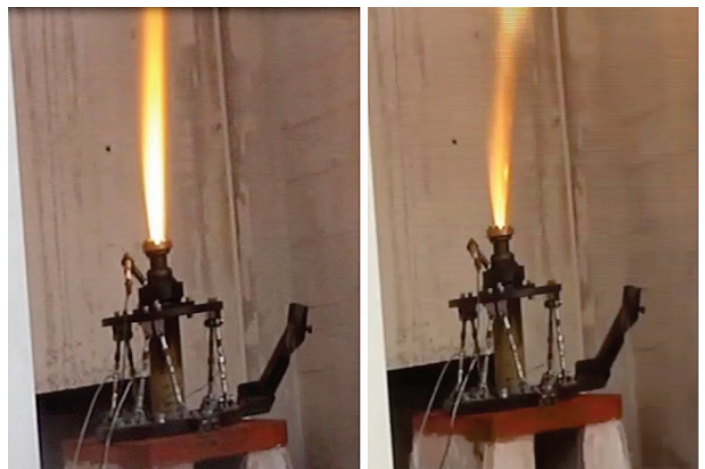

Figure 12 Rocket motor on test stand during operating $\left(10 \%, 20 \% A_{\mathrm{eb}}\right)$

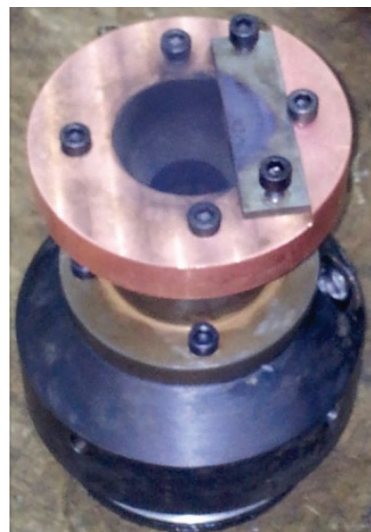

Figure 13 Nozzle after test with tab blocking $20 \%$ of exist area

\section{Test results}

First test was without any tab. This test will be used as a benchmark, to compare these results with other tests results in which variant percentage of the nozzle exit area was blocked $A_{\mathrm{eb}}$. It is also known that, in this first test, side force must be zero. Thus if some other result was to be obtained that would be a signal that something went wrong for sure. Results are presented in the following Fig. 14 and Fig. 15.

Test stand is of vertical type, thus consumed propellant mass has influence on results and has to be incorporated in calculation [7]. Measuring of pressure vs. time will help us in that. First the characteristic velocity needs to be calculated by formula:
$C^{*}=\frac{\int_{t 0}^{t e n d} P A_{c r} \mathrm{~d} t}{\Delta m}$

After that it is possible to calculate how much propellant mass is consumed over any time interval by using formula:

$\Delta m_{t i, t j}=\frac{\int_{t i}^{t j} P \mathrm{~d} t}{C^{*}}$

Consumed mass from time zero up to current time in calculation should be added to the value of $Z$ force in that moment to get a real force in $Z$ direction, so called $F_{\text {ztotal }}$. Total impulse of side force is negligible so it can be claimed that the observed system works correctly in this case.

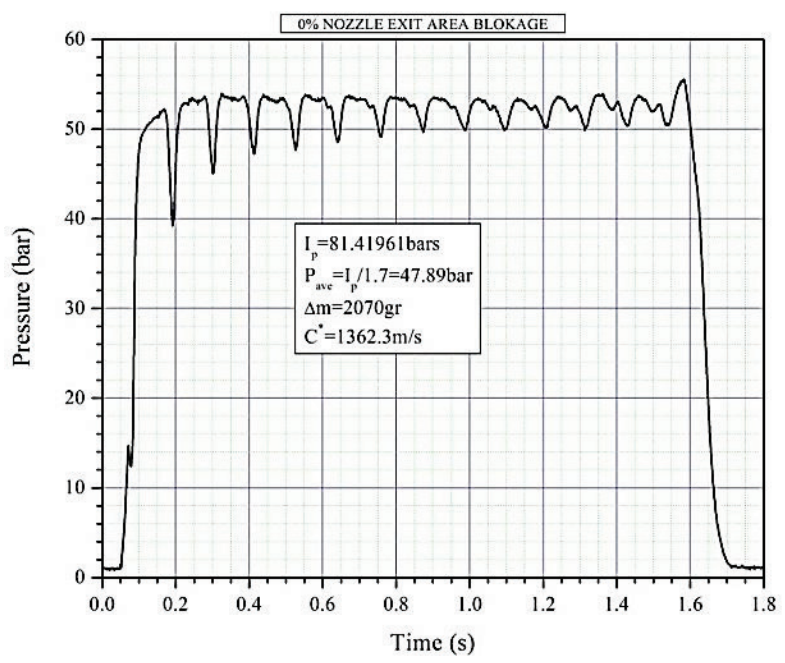

Figure 14 Pressure vs. time

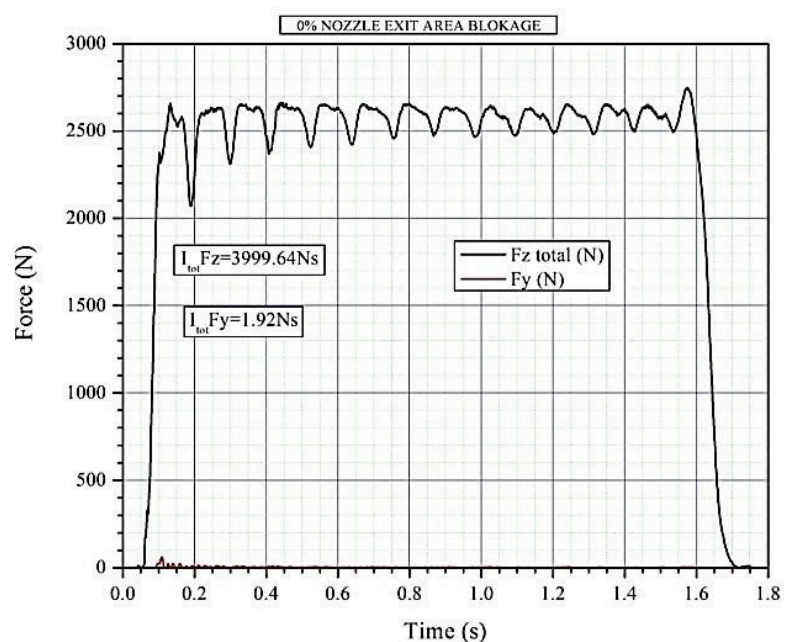

Figure 15 Thrust and side force vs. time

From measured $M_{x}$ and $M_{y}$ moments it is possible to calculate position of thrust vector in $X Y$ plane, rightly assuming that side force in $X$ axis direction is zero. Applying moment equations is obtained:

$x=-\frac{M_{y}}{F_{z}}$

$y=\frac{M_{x}+z \cdot F_{y}}{F_{z}}$ 


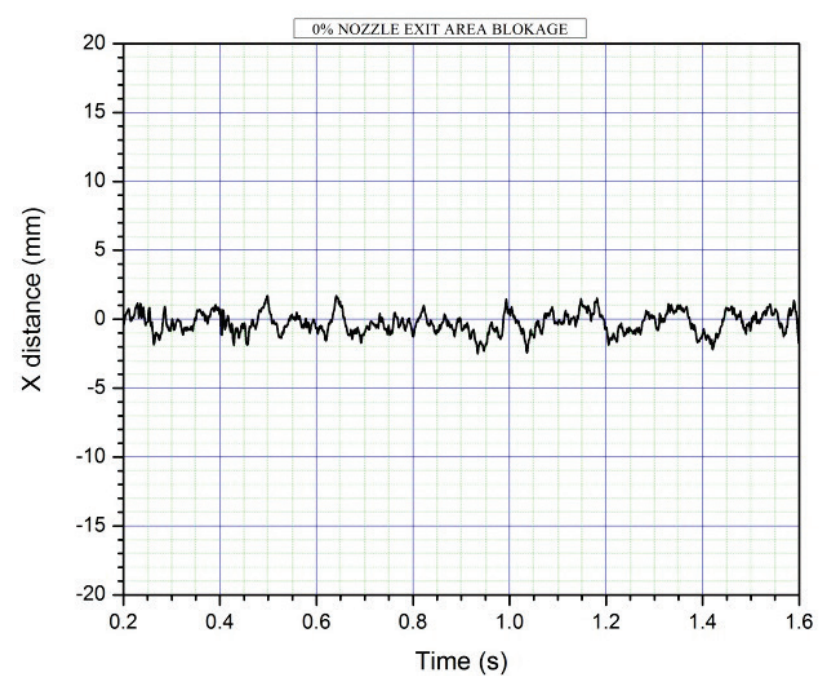

Figure $16 X$ position of result thrust vs. time

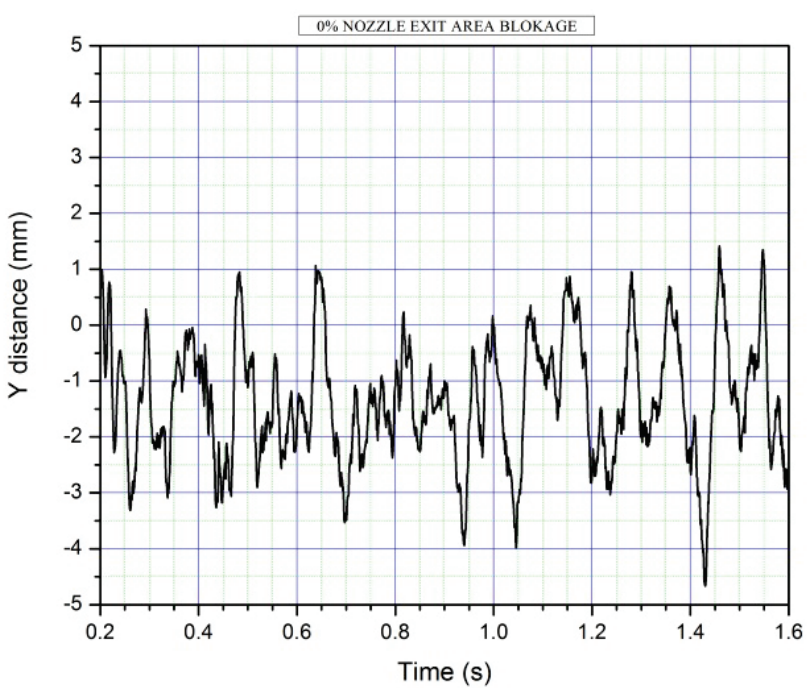

Figure $17 \mathrm{Y}$ position of result trust vs. time

Tests were conducted with different percentage of blocked nozzle exist area and obtained results are presented in Figs. 18 to 25.

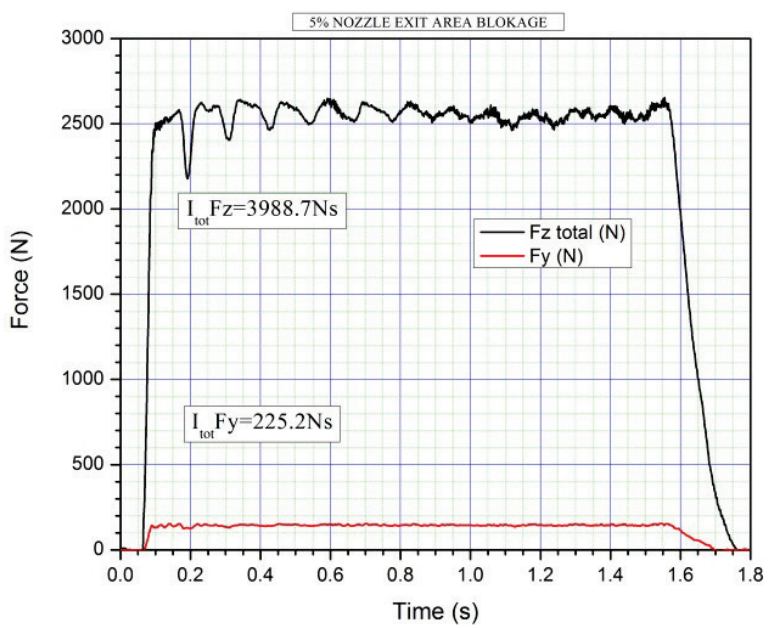

Figure 18 Thrust and side force vs. time for $A_{\mathrm{eb}}=5 \%$

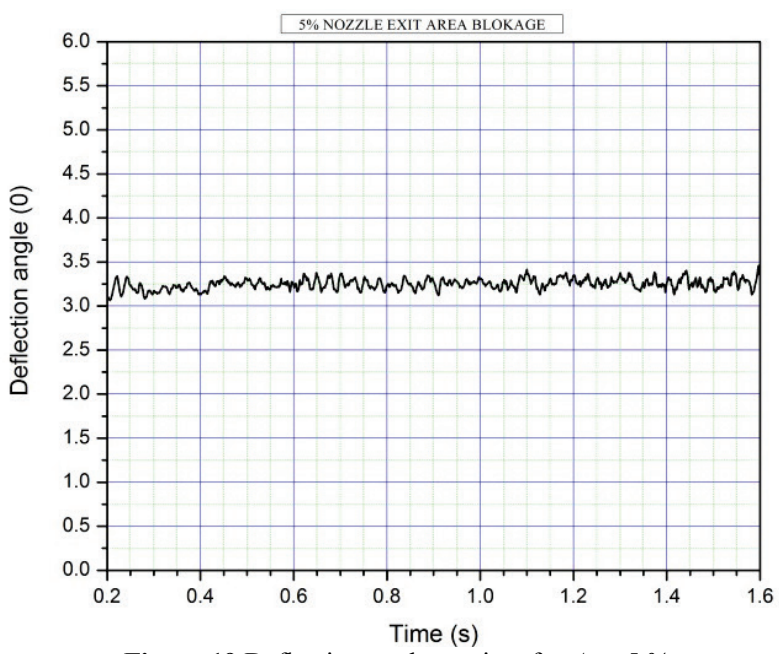

Figure 19 Deflection angle vs. time for $A_{\mathrm{eb}}=5 \%$

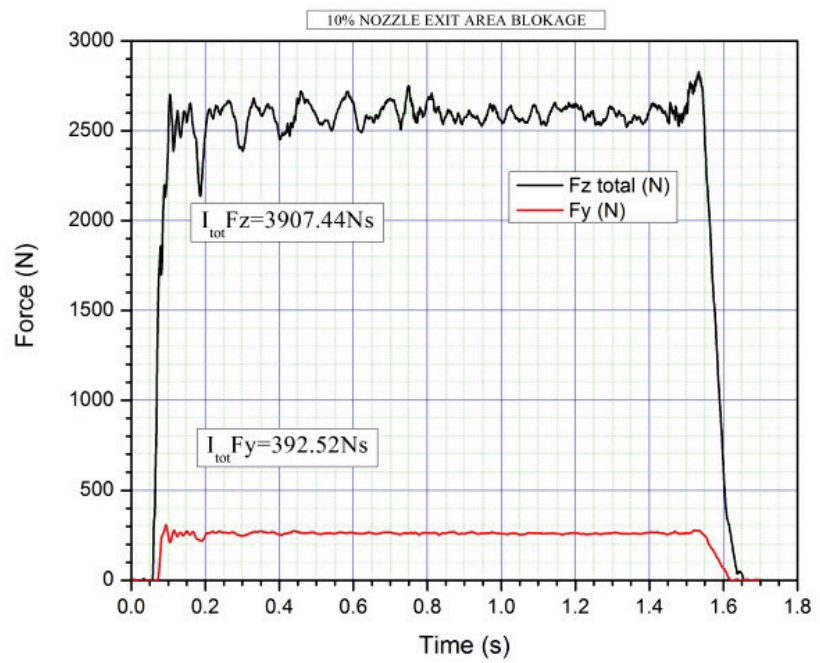

Figure 20 Thrust and side force vs. time for $\mathrm{A}_{\mathrm{eb}}=10 \%$

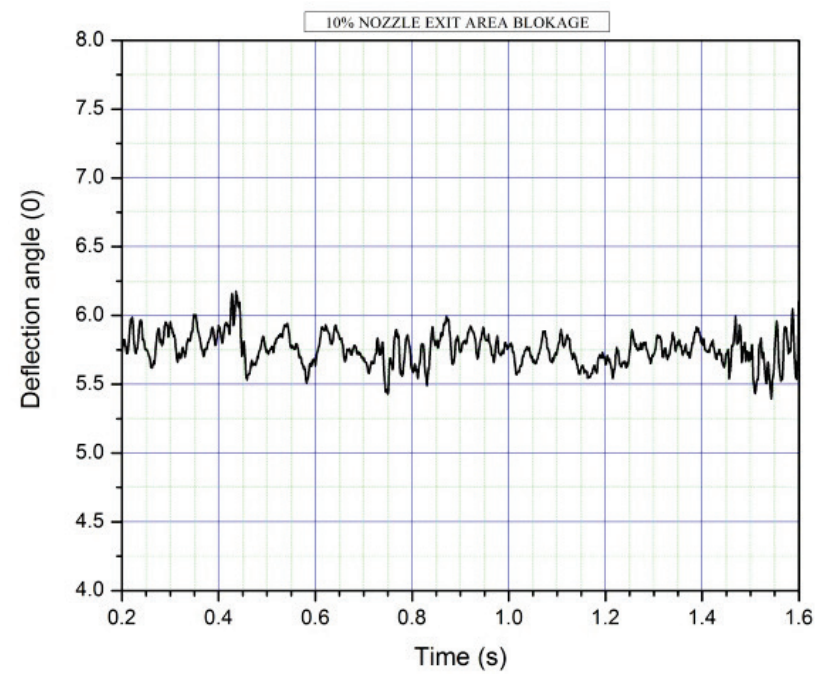

Figure 21 Deflection angle vs. time for $A_{\mathrm{eb}}=10 \%$

From the measured axial $F_{z}$ and side $\mathrm{F}_{\mathrm{y}}$ forces we can calculate main parameters for judging the performances of our jet tab TVC system. Of great importance are: absolute loss of thrust $\Delta F$, relative loss of axial force $\Delta F_{z \text { rel. }}$, relative side force $F_{\text {yrel., }}$, and deflection angle $\alpha$.

$\Delta F=1-\frac{\int F_{A e b}}{\int F_{0}} * \frac{\Delta m_{0}}{\Delta m_{A e b}}$ 
where total thrust with jet tab is calculated by:

$$
\begin{aligned}
& F_{\mathrm{Aeb}}=\sqrt{F_{z \mathrm{Aeb}}{ }^{2}+F_{y \mathrm{Aeb}}^{2}} \\
& \Delta F_{z \text { rel. }}=1-\frac{\int F_{z A e b}}{\int F_{z 0}} * \frac{\Delta m_{0}}{\Delta m_{A e b}} \\
& \Delta F_{y \text { rel. }}=\frac{\int \mathrm{F}_{\mathrm{yAeb}}}{\int \mathrm{F}_{\mathrm{zo}}} * \frac{\Delta \mathrm{m}_{0}}{\Delta \mathrm{m}_{\mathrm{Aeb}}} \\
& \alpha=\operatorname{arctg}\left(\frac{\int F_{y \mathrm{Aeb}}}{\int F_{\mathrm{z} 0}}\right)
\end{aligned}
$$

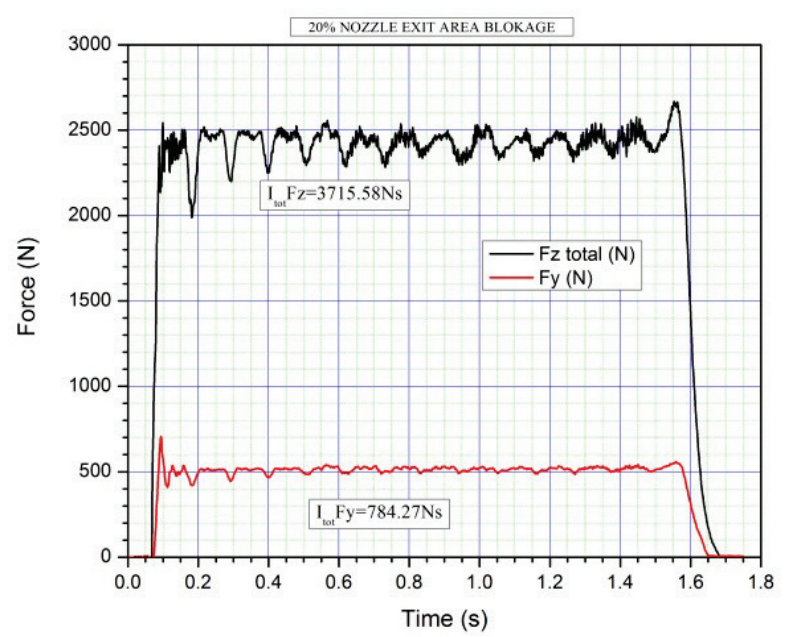

Figure 22 Thrust and side force vs. time for $A_{\mathrm{eb}}=20 \%$

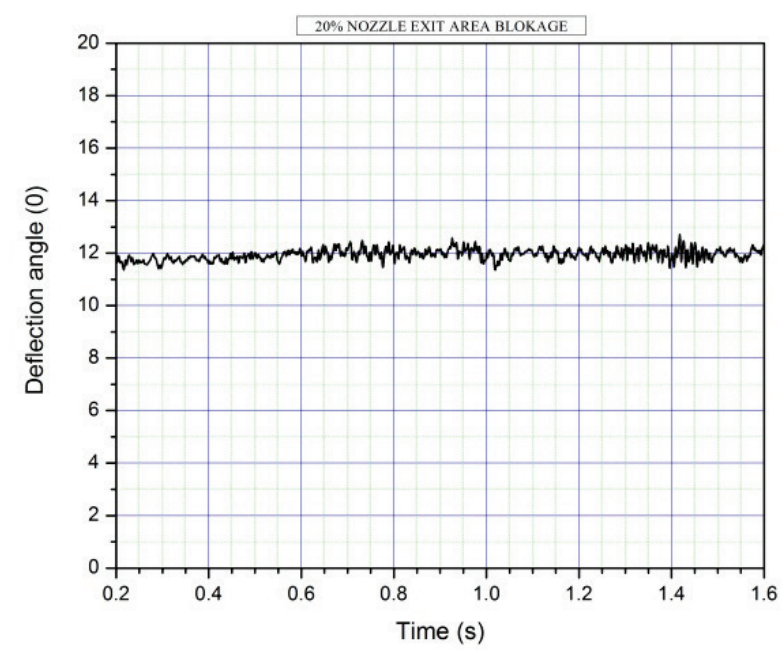

Figure 23 Deflection angle vs. time for $A_{\mathrm{eb}}=20 \%$

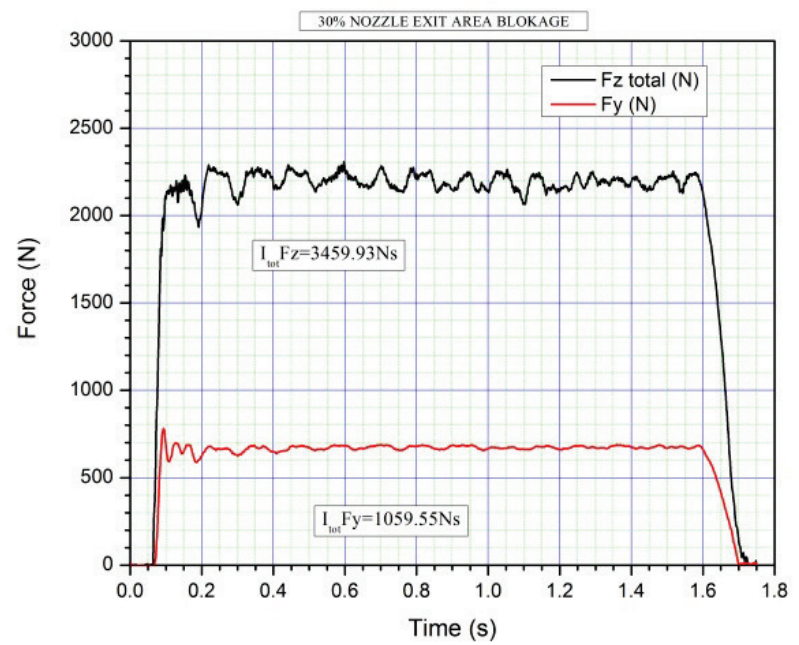

Figure 24 Thrust and side force vs. time for $A_{\mathrm{eb}}=30 \%$

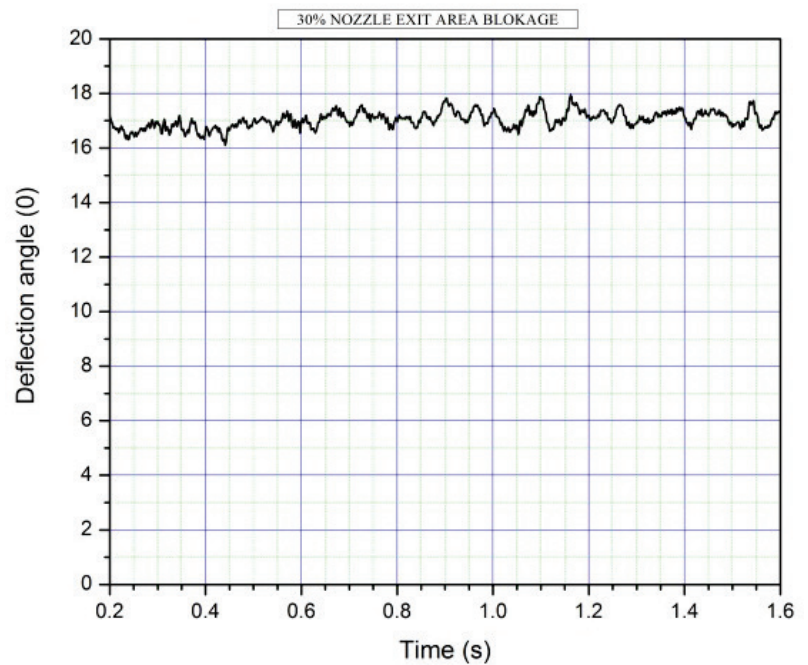

Figure 25 Deflection angle vs. time for $A_{\mathrm{eb}}=30 \%$

Table 7 Summary results
\begin{tabular}{|c|c|c|c|c|c|c|c|}
\hline$A_{\mathrm{eb}}$ & $\int F_{z}$ & $\int F_{y}$ & $\Delta m$ & $\Delta F$ & $\Delta F_{z \text { rel. }}$ & $\Delta F_{y \text { rel. }}$ & $\alpha$ \\
\hline$\%$ & $\mathrm{Ns}$ & $\mathrm{Ns}$ & $\mathrm{kg}$ & $\%$ & $\%$ & $\%$ & 0 \\
\hline 0 & 3999,6 & - & 2,070 & - & - & - & - \\
\hline 5 & 3988,7 & 225,2 & 2,070 & 0,1 & 0,3 & 5,6 & 3,2 \\
\hline 10 & 3907,4 & 392,5 & 2,055 & 1,1 & 1,6 & 9,9 & 5,7 \\
\hline 20 & 3715,6 & 784,3 & 2,045 & 3,9 & 6,0 & 19,9 & 11,9 \\
\hline 30 & 3459,9 & 1059,6 & 2,070 & 9,5 & 13,5 & 26,5 & 17,0 \\
\hline
\end{tabular}

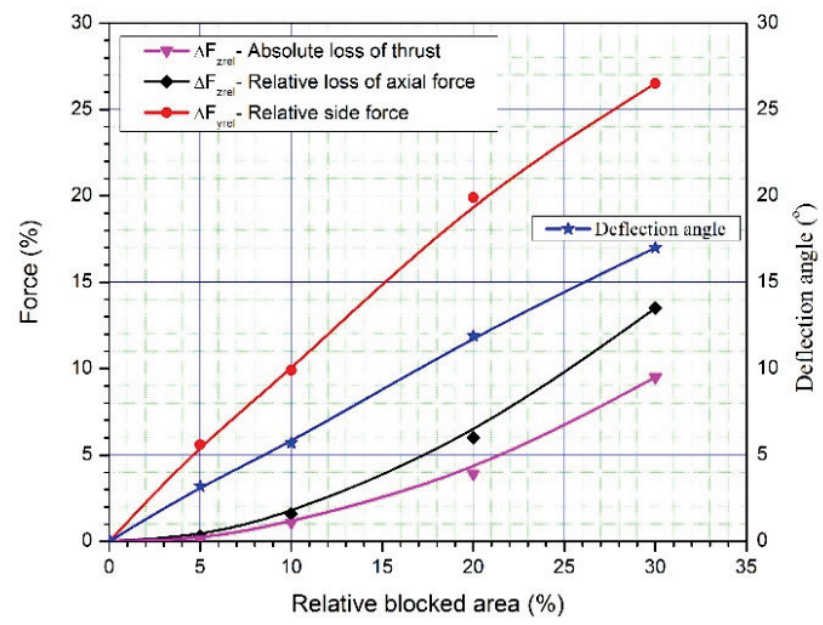

Figure 26 Test results as a function of relative nozzle exit area blockage

\section{Conclusion}

Regardless of the fact that for measurement of presented single and not movable jet tab TVC system it is not necessary to have test stand with more than 2 DOF (because position in space of jet tab is known and remains invariable) up to 4 load cells were used. The reason for that is to validate results and to prove the concept. By comparing the obtained results to the other published results [4] and some theoretical models [3], as well as by performing analysis of results it can be concluded that it is possible to use this type of the test stand for accurate measuring of the rocket motor thrust in space with all 6 degrees of freedom. Although this study only outlines the results of tests with jet tab, this test stand can be used for testing other TVC's systems in both static and dynamic conditions. Excellent results of testing domed deflector TVC system in dynamic conditions were obtained. Design 
and manufacturing of presented test stand is very simple and does not require special precision. Even an inaccurate symmetry of the test stand (all rods are not at the same angle to the bottom or/and upper plate) does not present a problem, because by calibration the exact test stand response can be obtained, and that is the only thing important.

\section{$7 \quad$ Notice}

Version of this paper has been presented and published in "Proceedings of $2^{\text {nd }}$ International Conference on Manufacturing Engineering \& Management 2012" [10]. Also, the paper "has been awarded the ICMEM 2012 best paper award" (signed by chairperson of the Scientific and Conference Committee).

\section{Acknowledgements}

Research of this paper is the result of the national project financed by the Serbian Ministry of Education and Science (TR 35044).

\section{References}

[1] Zarchan, P. Editor in Chief: Tactical Missile Propulsion, Volume 170 Progress in Astronautics and Aeronautics, American Institute of Aeronautics and Astronautics, Inc, 1996.

[2] Sutton, G. P.; Bilbarz, O. Rocket Propulsion Elements $7^{\text {th }}$ edition, A Wiley-Intersience Publication, 2000.

[3] Jojić, B.; Blagojević, Đ.; Fotev, V.; Marko, M. et al. Rocket propulsion research-thrust vector control, Jet Propulsion Laboratory Faculty of Mechanical Engineering University of Belgrade, 1984-1986.

[4] Eatough, R. G. Improved jet tab thrust vector control for the BGM-34C booster, Final report AFRPL TR-77-49, May 1975-June 1977.

[5] Raketni motori sa čvrstom pogonskom materijom, izabrana poglavlja, Vojnotehnički institut Beograd, 2012.

[6] Solid Rocket Thrust Vector Control, NASA Space Vehicle Design Criteria (Chemical Propulsion), SP-8114, December 1974

[7] Captive-Fired Testing of Solid Rocket Motors, NASA Space Vehicle Design Criteria (Chemical Propulsion), SP8041, March 1971

[8] Solid Rocket Thrust Vector Control (TVC), AIAA Lecture Series, Reno, NV, January 9-12 1995

[9] Jet vane and Jet tab TVC Technology, a Bibliography, Chemical Propulsion Information Agency, CPIA-LS-88-04, May 1998

[10] Miloš, P.; Davidović, N.; Jojić, B.; Blagojević, Dj.; Miloš, M. 6 DOF Thrust Vector Control Test Stand Based on Stewart Platform Design. // Proceedings of $2^{\text {nd }}$ International Conference on Manufacturing Engineering \& Management 2012, Presov, Slovak Republic, December 5-7, 2012, pp. 113-121.

\section{Authors' addresses}

Predrag Miloš, Ph.D.

EDePro Company

Kralja Milutina 33, 11000 Belgrade, Serbia

E-mail: predrag.milos@edepro.com

Nikola Davidović, Ph.D.

EDePro Company

Kralja Milutina 33, 11000 Belgrade, Serbia

E-mail: nikola.davidovic@edepro.com

Branislav Jojić, Ph.D., full time professor

Faculty of Mechanical Engineering University of Belgrade Kraljice Marije 16, 11000 Belgrade, Serbia

E-mail: branislav.jojic@edepro.com

Marko Miloš, Ph.D., associate professor

Faculty of Mechanical Engineering, University of Belgrade Kraljice Marije 16, 11000 Belgrade, Serbia

E-mail:mmilos@mas.bg.ac.rs

Ivana Todić, Ph.D., assistant

Faculty of Mechanical Engineering, University of Belgrade Kraljice Marije 16, 11000 Belgrade, Serbia

E-mail: itodic@mas.bg.ac.rs 